\title{
The Effect of Access to Debt on Lebanese Small and Medium Enterprises Performance
}

\author{
Zainab Abdulawood Jadoua*, Nihal Farid Mostapha \\ Beirut Arab University
}

\section{ARTICLE INFO}

\section{Article history:}

Received 29 October 2019

Revised 05 February 2020

Accepted 17 February 2020

Published 31 March 2020

\section{Keywords:}

SMEs performance

Access to debt

Trade off theory

Pecking order theory

Assets structure

Tangibility

Profitability

\begin{abstract}
Since thirties access to debt has been considered as one of the main challenges facing the growth of Small and medium-sized enterprises (SMEs). Therefore, empirical studies focused on how facilitating access to debt affects SMEs financial performance in developed countries. However, this is not the case in the developing economies countries such as Lebanon due to the lack of financial transparency and poor financial reporting. In addition, very few studies discussed the theoretical pillar behind SMEs financial behavior on how access to debt affects firm performance in developed and developing countries. Therefore, this study attempts to investigate the effect of access to debt on Lebanese SMEs financial performance in terms of profitability and tangibility. In addition, the study explores the theoretical explanation of how Lebanese SMEs access to debt affects profitability (PR) and tangibility (ST) using trade-off theory (TOT) and pecking order theory (POT). Data of 102 SMEs for the period 2014 till 2017 from 12 official audit firms located in Beirut-Lebanon. Additionally, generalized least squares (GLS) method was used to conduct regression analysis. The analysis reveals the positive effect of Lebanese SMEs access to debt on SMEs profitability and tangibility confirming the adoption of trade-off theory as an approach by Lebanese SMEs and lenders. It is concluded that facilitating Lebanese SMEs access to debt to reach proper debt level improves SMEs performance which in return affects positively the lenders and economy as whole.
\end{abstract}

\section{Introduction}

The importance of SMEs increased in 1931, when the government of the United Kingdom sponsored the Macmillan Committee to define the root causes of the declining economy. The Committee realised that one of the primary causes was the unmet financial needs of SMEs that should be supported by the government to improve their performance (Carter \& Evans, 2000, p.339). Since that point, many studies have focused on how access to debt affects SMEs' performance and growth. Such growing interest represents an attempt to spread awareness around how access to debt can increase profits, growth, innovation and jobs to positively affect the economy (Goldhausen, 2017). In the US, SMEs constitute $99.7 \%$ of total firms, create approximately $70 \%$ of new jobs and contribute approximately $51 \%$ of private GDP (Scarborough, 2011, p.41). Meanwhile, in Europe SMEs constitute about $99.8 \%$ of total firms, create approximately $66 \%$ of new jobs (Daskalakis \& Psillaki, 2006) and contribute approximately $57.4 \%$ of added value to the GDP (Muller et al., 2016). In developing countries such as Singapore, SMEs create about 68\% (Vandenberg, Chantapacdepong \& Yoshino, 2016). In addition, SMEs play a major role in lowering the poverty level (Vandenberg et al.,2016), increasing exports (Vandenberg et al., 2016), boosting competition (Kaseb \& Kamal El Din, 2007, p.13) and supporting sustainable development (Ayuso \& Navarrete-Baez, 2018). Therefore, SMEs are key drivers to boost productivity and growth (Scarborough, 2011, p.42).

Defining the effect of access to debt on SMEs' performance has been the focus of many studies (Kokoreva \& Stepanova, 2012; Wahba, 2013; Iavorskyi, 2013; Dennis, Achesa \& Gedion, 2015; Manini, Abdillahi, Wanyama \& 
Simiyu, 2016; Vijayakumaran, 2017; Matsumoto \& Matsumoto, 2017; Malaeny, Pasda \& Haerani, 2018; Domnick, 2018). The literature has heavily focused on the importance of SMEs' access to debt due to the direct effect of access to debt on SMEs' performance, which consequently affects the economy as whole. However, previous studies considered the effect of access to debt on different sets of performance indicators. Such studies suggest that firm performance in terms of growth can be measured in different ways, such as firm size (Delmar, Davidsson \& Gartner, 2003; Zhou \& Wit, 2009; Moreira, 2016; Hamouri, Al-Rdaydeh \& Ghazalat, 2018), assets (Andree \& Kallberg, 2008; Mateev \& Anastasov, 2010; Li, Jinfeng \& Xuezhu, 2012; Nawi, 2015; Jeger, Sarlija \& Bilandzic, 2016; Goldhausen, 2017; Ando, Matsumoto \& Matsumoto, 2017), revenue and profit (Baum, Schafer \& Talavera, 2007; Kebewar, 2012; Li et al. , 2012; Wang, 2013; Tang, 2014; Popa \& Ciobano, 2014; Nawi, 2015; Ramadan, 2015; Abeywardhana, 2015; Muscettola \& Naccarato, 2016; Schulz, 2017; Goldhausen, 2017; Malaeny et al. , 2018) and innovation and exports (Harvie, Narjoko \& Oum, 2013; Amornkitvikai \& Harvie, 2016). However, the results on the effect of access to debt on profitability and assets are contradictory, varying from a positive effect to a negative effect or insignificant effect. Other studies have found mixed results through dividing debt into short-term debt and long-term debt.

In Lebanon, SMEs constitute about $96 \%$ of registered firms, employ $50 \%$ of the working force and produce $27 \%$ of total revenues (International Monetary Fund \& World Bank, 2016). Lebanese SMEs are characterized by family ownership, centralised management, usage of simple systems, interrupted internal growth, financing problems and a preference for internal financing (Naimy, 2004). In recognition of the importance of SMEs to the economy, Lebanese authorities have launched several initiatives to resolve the finance gap, such as the Kafalat program, credit guarantees, Reserve Requirements Exemption Program (RREP), subsidised lending program and support for start-up enterprises through interest-free loans of up to seven years. Several commercial banks have also established SME units to improve the facilities and services for SMEs. However, the effects of these programs on SMEs' performance and thereby the economy are not clear due to the lack of observation systems (International Monetary Fund \& World Bank, 2016). Moreover, about $42 \%$ of micro and small enterprises are restricted by lack of access to debt (Hamdan, 2016), and only $20 \%$ of private sector credit is provided to SMEs, reflecting poor finances, the inability of SMEs to provide required collateral, and poor business plans (Naimy, 2004). Farran and Fawaz (2018) argued that war and inequity in Lebanon have led to structural tardiness, which in turn has led to the delay of Lebanese SMEs. At the same time, lenders confront challenges in evaluating the performance and loan risks of Lebanese SMEs due to the lack of financial transparency and poor financial reporting, which affects SMEs' access to debt (Naimy, 2004). This lack of financial data has resulted in limited empirical studies in Lebanon on SMEs in general.

The increasing interest in exploring and analysing SME growth (Davidsson, Achtenhagen \& Naldi, 2006) and in considering SMEs as major contributors to the economy (Matta, 2018) are key drivers for conducting this study. This research examines SMEs and lenders in Lebanon, a developing country, in order to offer evidence around how access to debt affects SMEs' financial performance based on capital structure theories. According to the researcher's knowledge, there are no empirical studies that have been conducted in Lebanon on this subject to date. The contribution to the literature matches the drivers behind the study. The World Bank (2008) and European Investment Bank (2011) affirm that there is a scarcity of systematic information on SMEs in developing countries and a lack of empirical evidence connecting access to debt to SME performance and to effects on the economy as whole. Moreover, the lack of financial transparency and poor financial reporting in Lebanon (Naimy, 2004) affect the empirical research on Lebanese SMEs and limit the empirical research in these areas. This research therefore presents empirical evidence from a developing country on how access to debt affects SMEs' performance in terms of profitability and tangibility based on capital structure theory.

Previous studies have adopted capital structure theories to explain the causal relationship between access to debt and SME performance. Some studies have used the capital structure effect as a term to reflect the leverage effect on firm performance, including Andree and Kallberg (2008), Iavorskyi (2013), Nawi (2015), Schulz (2017) and Malaeny, Pasda and Haerani (2018). I contrast, other studies are more clear in defining the effect of debt on SMEs' performance based on capital structure theories, including the work of Mateev and Anastasov (2010), Ramadan (2015), Manini et al. (2016) and Goldhausen (2017). Nevertheless, there are limited studies in developing countries that address the effect of access to debt on firm financial performance based on capital structure theories. Moreover, even fewer studies have presented the direct effect of access to debt on the profitability and tangibility of firms in a developing country.

Therefore, this study aims to fill this gap by examining the primary effects of access to debt on SME performance in developed and the developing countries. The study specifically explores the effect of access to debt on Lebanese SMEs' performance. It also examines the financial behaviour approach that is adopted by Lebanese SMEs in terms of trade-off theory or pecking order theory regarding how to use access to debt to affect the profitability and tangibility of SMEs. Based on previous studies, this research adopts profitability and tangibility to reflect firm performance by 
collecting data from 102 Lebanese SMEs for the period 2014-2017. SMEs in developing countries are defined by different criteria in terms of the number of employees. For instance, the World Bank Group adopts the ceiling of 100 employees as the main criterion to distinguish SMEs from large firms (Alibhai, Bell, \& Conner, 2017), while the United Nations (2019) considers 250 employees as the maximum number to consider a firm a SME. This study adopts the Lebanese Ministry of Economy and Trade's (2014) criterion of 100 employees to distinguish SMEs.

The remainder of this paper is organised as follows: the following section discusses the effect of access to debt on SMEs performance theoretically and empirically and outlines the hypotheses for this study. The subsequent sections present the methodology, analysis and results of the descriptive and regression analysis. Finally, the concluding sections present the interpretation of the findings in this study, conclusions and limitations.

\section{Theoretical Background and Literature Review}

This section provides a comprehensive overview of how access to debt can affect SMEs' performance by presenting the theoretical background and literature review to support the hypotheses for this study.

\section{SMEs Capital Structure Theories and Access to Credit Behaviour}

Modigliani and Miller (MM) proposed a theory in 1958 with two propositions. The first proposition assumes that the leverage ratio will not affect the value of a firm in a world without taxes. The second proposition suggests that in a world with taxes and no financial distress costs, the value of a firm increases with a high leverage ratio (Ross, Westerfield \& Jaffe, 2013, p.490-502). Since the introduction of this theory, several theories have emerged to balance between maximising the value of the firm and minimising the cost of capital (Abeywardhana, 2015), namely tradeoff theory (TOT) and pecking order theory (POT), which are used by firms to manage their capital structure (Ross et al., 2013, p.548).

Kraus and Litzenberger (1973) established trade-off theory to suggest that an increasing level of debt in capital structure would increase bankruptcy risk through the difficulty of repaying the interest and principal payment (Kythreotis, Nouri \& Soltani, 2018). In contrast, Ehrhardt and Brigham (2011, p. 613) focused on bankruptcy costs, suggesting that an increasing level of debt may lead to higher legal and accounting expenses, difficulty in retaining customers who will search for other stable suppliers, difficulty in retaining employees who will leave a failing firm, declining relations with suppliers who will refuse to giving credit and the obligation to sell assets for a lower price. As a result, firms select a target ratio of debt and equity by trading off cost and benefits to reach the optimal debtequity ratio mix that can maximise the profit and minimise the finance cost (Abeywardhana, 2015).

In 1984, the scholarly focus shifted to pecking order theory, established by Myers (Ross et. al, 2013, p. 543). According to Myers (1984), firms prefer to adopt a sequential approach in financing their requirements by using internal funds first then debt as a second approach and finally external equity (Dennis et al., 2015). Therefore, as SME managers concentrate on maximising profit and minimising cost, they would adopt the lower cost approach. In this case, a manager prefers to use retained earnings instead of debt for raising funds.

Access to Debt (AD) and Profitability (PR)

Most studies in the literature consider profitability as a primary firm performance indicator. Although many studies have noted the effect of profitability on access to debt based on capital structure theories, very few studies have mentioned how access to debt affects profitability based on capital structure theories. Nawi (2015) explained the effect of access to debt on profitability under TOT and POT perspectives. According to TOT, an optimal capital structure helps firms to decrease financing capital cost and thereby improves firms' financial performance. Therefore, TOT suggests positive effect of access to debt on profitability. Indeed, many studies have confirmed the positive effect of access to debt on SME profitability, which supports the adoption of TOT. Li et al. (2012) and Wang (2013) analysed Chinese SMEs and reached similar results. Both studies confirm that access to debt leads to an increase in SME profits, but each author explained the effect of access to debt from a different perspective. Wang (2013) suggested that all those firms increase the debt to double witness an increase in profitability by $3 \%$. Meanwhile, SMEs with a low level of productivity and low level of retained earnings request access to long-term debt. These SMEs use debt to improve their performance by making more investment in assets or renewing technology and equipment. In contrast, Li et al. (2012) considered only SMEs operating in the manufacturing industry and concluded that SMEs are struggling to gain access to debt because of financing obstacles, a low level of innovation and resistance 
to accept risk to seize opportunities. These points are the main reasons behind the weak growth rate of manufacturing SMEs' profitability.

Manini et al. (2016) agreed with Wang (2013) that SMEs tend to gain access to debt to develop and expand their operations, which consequently affects their profitability. Although SMEs in Kenya use commercial loans, retained earnings and trade credit financing, they still consider commercial loans as the primary external financing source. These loans are used to boost profits, revenue, assets and sales growth. However, SMEs balance the financing process between internal and external sources in order to lower financing costs, increase profitability and eventually grow and enhance financial performance. Hamouri et al. (2018) explained the reasons behind the positive effect of access to debt on the profitability of listed firms in the Amman Stock Exchange. The authors indicated that good management and using mostly short-term debt and overdrafts provides the firms the chance to control and manage debts easily while improving their financial position and reputation. Therefore, it is easy for such firms to gain access to debt whenever they need.

As for POT, Nawi (2015) suggested that focusing on using internal funds may prevent a firm from growing or even surviving, especially under conditions of aggressive competition, a fast-paced environment and rapid technological and innovation progress. Therefore, a negative effect of access to debt on profitability derives from the fact that a higher level of debt leads to a low level of long-term capital investments, which negatively affects firm performance. Several studies have proved the negative effect of access to debt on profitability through adopting the POT perspective, confirming the negative effect of access to debt on profitability in terms of return on assets (Iavorskyi, 2013; Kebewar, 2013; Schulz, 2017; Goldhausen, 2017; Malaeny, Pasda \& Haerani, 2018). Goldhausen's (2017) study on Dutch firms operating in various industries found that banks in the Netherlands are not supporting SMEs by giving them the required finance to grow, which forces SMEs to use internal funds instead and thereby negatively affects their growth in terms of profitability. In contrast, Iavorskyi's (2013) and Kebewar's (2013) studies of Ukrainian and French SMEs respectively explained the negative effect of debt on profitability as normal consequence for high-growth firms, while low-growth firms exhibit a positive effect of leverage on return on assets. Iavorskyi argued that high-growth firms are obliged to meet their regular financial commitments related to accessing debt, which in return forces the firm to delay its profitable plans. Schulz (2017) agreed with Iavorskyi (2013) and Kebewar (2013). According to Schulz, Dutch SMEs reflect POT by affirming the negative effect of all types of debts in terms of total leverage, long-term debt and short-term debt divided by total assets on profitability. The author explained that SMEs using debt to finance their business activities and investments are less profitable firms. Therefore, they seek access to debt to meet their financial commitments.

Popa and Ciobano (2014), Ramadan (2015) and Malaeny et al. (2018) suggested that a high level of leverage leads to higher costs in terms of interest rate and increased investment cost, which consequently decreases the profitability of firms. The results of their studies revealed a negative relationship between debt and firm performance, as access to debt led to capital cost, represented by the interest cost charged by the lender. At the same time, there were opportunity costs of the financing used. Such costs could be a signal for improper capital structure decisions made by the managers that led to low profitability and consequently jeopardised the firm's financial position. However, Nawi (2015) provided a different explanation: the negative effect of access to debt on profitability is justified by the case of SMEs in Malaysia, which do not see a tax shield as an advantage by securing access to debt and prefer taking a safer path to grow by using internal funds instead of external funds.

Although previous studies have confirmed either a positive or negative effect of access to debt on profitability, some studies have found mixed results, including the work of Baum et al. (2007), Yazdanfar (2012), Tang (2014) and Abeywardhana (2015). The studies of Baum et al. (2007) and Yazdanfar (2012) examined the effect of shortterm and long-term debt on firm profitability and confirmed the positive effect of short-term debt on profitability due to the easier control or faster movement in seizing opportunities. In addition, both studies proved that long-term debt has no effect on profitability. Baum suggested that the lack of effect of long-term debt is related to the high sensitivity of long-term debt to the firm size, which affects the final results. Meanwhile, Yazdanfar (2012) studied the effect of financing patterns in different sectors. The results revealed a positive impact of retained earnings on growth in every sector, while short-term debt exhibited a positive impact on growth in all sectors except agriculture. This financing pattern clearly supports the application of a POT perspective in Sweden. Tang's (2014) conclusions aligned with those of Yazdanfar (2012), confirming the positive effect of short-term debt represented in trade credit on profitability. However, Tang also proved the negative effect of long-term debt on profitability due to the high interest rate that affects the investment costs. Furthermore, Abeywardhana (2015) specifically considered the effect of debt on the profitability of SMEs located in the United Kingdom. The study proved that short-term debt positively affects profitability, while long-term debt negatively affects profitability. The author considered these results as proof that profitable SMEs prefer using short-term debt over long-term debt in funding operations in the United Kingdom due 
to the higher cost of long-term debt, which negatively affects the profitability of the firm. However, Wahba's (2013) study on Egyptian SMEs provided contradictory results to Abeywardhana's study. Wahba's results demonstrated a negative effect of short-term debt on profitability in terms of return on assets, and a positive effect of long-term debt on return on assets. The results demonstrated that it is not the level of debt that determines financial performance, but rather the debt maturity structure. Thus, the results suggest that short-term and long-term debt have an opposite effect on financial performance and therefore tend to cancel out.

Although many studies have found for a positive or negative affect of access to debt on profitability, there are few studies, such as that of Kebewar (2012), that have demonstrated no effect of access to debt. Kebwar's study analysed the data of French firms operating in the service industry for the period 1999-2006 to examine the impact of debt on firm profitability. The sample contained different sizes of firms, including 2,162 SMEs and 78 large firms. The study did not find any effect of debt on profitability regardless of the size of the firm. Therefore, based on the previous discussion, this study poses the following hypothesis based on TOT:

H1: Access to debt has a positive significant effect on SMEs profitability in Lebanon.

Access to Debt (AD) and Assets Structure (ST)

As for the second measure of firm's growth in terms of assets, studies generally consider two types of growth. The first type is the growth in total assets from year to year, as explored by Mateev and Anastasov (2010), Li et al. (2012), Goldhausen (2017) and Ando, Matsumoto and Matsumoto (2017). The second type of firm growth is tangibility. Most studies consider tangibility to be synonymous to asset structure, which describes the proportion of fixed assets of a firm. According to Jeger et al. (2016), assets structure is a vital indicator of firm growth in the future of SMEs. The following paragraphs outline previous studies on the effect of access to debt on assets structure, noting that there are very few studies that have explored the effect of access to debt on firm performance (Nawi, 2015). According to the researcher's knowledge, there are even fewer studies focusing on the effect of access to debt on tangibility in particular. However, many studies focusing on the effect of access to debt on profitability have considered assets structure as a control variable that has a significant effect on profitability (Kokoreva \& Stepanova, 2012; Iavorskyi, 2013; Vijayakumaran, 2017; Domnick, 2018).

Andree and Kallberg (2008) and Nawi (2015) explained the effect of access to debt on assets structure through the lens of TOT and POT. According to Shergill and Sarkaria (1999), no previous study examined tangibility and its relationship with firm performance; however, both authors stated that according to TOT, firms with high levels of fixed assets would face difficulties in confronting financial distress, as these assets can be liquidated and are productive and profitable resources that contribute positively to the financial performance. Therefore, with available assets that can be pledged as collateral, firms can more easily access debt and initiate successful projects that lead to better performance. However, based on POT, firms may not estimate the costs of bankruptcy properly, which leads to an increase in debt level that negatively affects performance in terms of tangibility.

Hall, Hutchinson and Michaelas (2000) and Andree and Kallberg (2008) divided debt into short-term debt and long-term debt in order to examine the effect of each type on assets structure. Both studies proved that short-term debt has a negative effect on tangibility, while long-term debt has a positive effect on tangibility. Andree and Kallberg (2008) argued that firms aim to match maturities of assets and liabilities; therefore, they maintain a positive relationship between fixed asset ratio and long-term debt ratio. This relationship would be negative if leverage ratio were mostly from short-term debt. Thus, SMEs should invest in non-current assets in order to attain such matching effects through the possibility of attaining long-term debt. Andree and Kallberg suggested that due to information asymmetry and the desire to avoid losing control over firms, it is obvious that SMEs adopt a POT approach. Harc (2015) agreed with Andree and Kallberg, confirming that Croatian SMEs use a maturity matching principle by financing long-term assets with long-term debt and financing short-term assets with short-term debt.

Additional studies, such as that of Nawi (2015), have considered debt without dividing debt into types and have proposed a negative relationship between access to debt and assets structure, supporting a POT perspective. Nawi's (2015) study found a negative effect of access to debt on Malaysian SMEs' performance using assets structure, business planning and profitability. The author suggested that higher debt levels may negatively affect the funds of profitable projects due to the financial commitments that must be paid, which would affect the firm performance in terms of fixed assets, current assets, business plan and ultimately profits. Jeger et al. (2016) considered the effect of financial determinants on the growth of SMEs located in Croatia and used assets as an indicator for SME growth to reflect the combination of tangibility. The findings demonstrated that during economic decline, the firms that use short-term debt witnessed better growth in terms of utilising their assets more efficiently. The results also confirmed 
the limited access to debt through banks during economic decline, especially when the request is submitted by new SMEs. Therefore, SMEs often use internal finance to grow and expand during recession. In addition, the study asserted that high-growth SMEs use fixed assets and current assets more efficiently than slow-growth SMEs. Meanwhile, SMEs with similar assets value and that are good at making revenues by using those assets or that can liquidate those assets faster would have a greater potential to grow. Therefore, based on the previous discussion, this study poses the following hypothesis based on TOT:

H2: Access to debt has a positive significant effect on SMEs assets structure in Lebanon.

\section{Methodology}

The data collection was conducted by approaching official audit firms located in Lebanon, Beirut and listed on the 5INDEX Business Directory Lebanon (2018). The researcher communicated with 208 listed audit firms. Twelve audit firms agreed to hold interviews and provided data from 102 SMEs' official financial statements reports no (11) and no (6) located in Beirut and operating during the period 2014-2017. A maximum of 100 employees was utilised as the main criterion to distinguish SMEs from large firms, according to the standard of the Lebanese Ministry of Economy and Trade (2014). Continuous follow-up with each audit firm was required to collect research data from June 2018 to June 2019. All of the participating audit firms have licenses and provide SMEs' financial statements to the government on an annual basis. Therefore, the researcher is confident in the validity and reliability of the data. In addition, the researcher considered the validity and reliability of the instruments in designing the study by employing two approaches. The first approach was to adopt all variables that are considered as standard measures of business activity. The second approach was to ensure that all variables were adopted for similar purposes in previous studies and that their related measures have been tested. Therefore, there was no need to test the validity of the measures (Kerlinger, 1992, p.443).

As all SMEs have the same number of repeated measurements made at equivalent time intervals, the data set is referred to as balanced longitudinal data (Everitt, 2002, p.31). According to Gujarati (2004, p.673) panel data helps in enhancing the accuracy of model parameters, as panel data provide more sample variability and a higher degree of freedom. In addition, panel data increase the capability of capturing the complexity of human behaviour and reveal the dynamic relationships of economic behaviour. Finally, it provides more informative and variable data and results in less collinearity among variables.

This research utilized the STATA 14 software to process and analyse the data collected. The researcher used a panel regression technique to examine how access to debt affects SMEs' profitability and to define the effect of access to debt on assets structure. For this purpose, the researcher applied multiple linear regression models adopting generalised least square (GLS) to define the cause and effect relationship between dependent and independent variables.

\section{Econometric model}

Equation no. 1 and 2 below present the econometric models of the first and second hypothesis respectively.

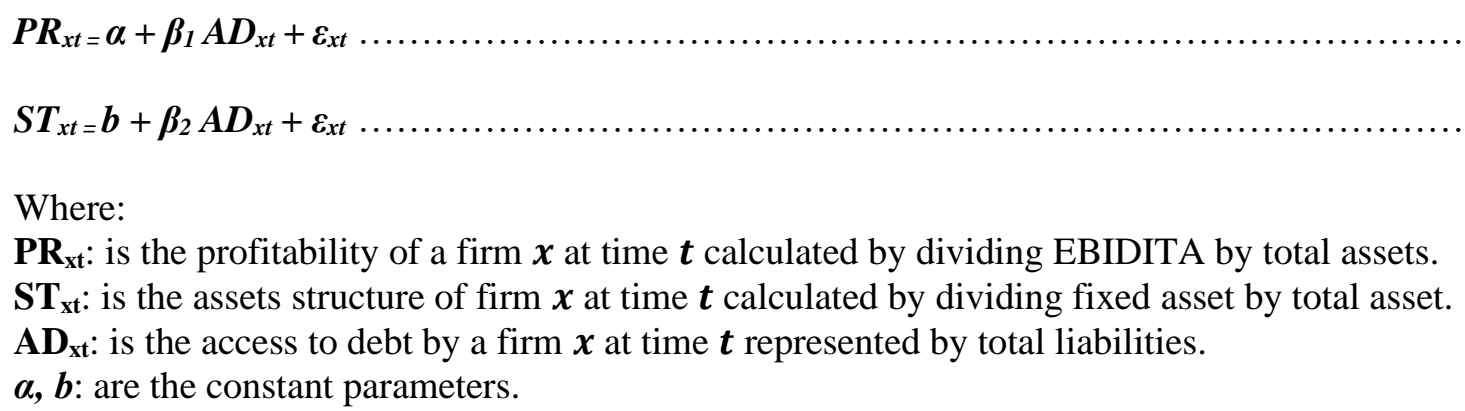

$\boldsymbol{\beta} 1, \boldsymbol{\beta 2}$ : are the coefficients of the independent variables or the regression parameters to be estimated, which are positively related to access to debt by a firm.

$\boldsymbol{\varepsilon}_{\mathrm{xt}}$ : is the error component that varies over firms at a given time. 


\section{Descriptive Statistics and Correlation Analysis}

Table 1 below presents an overview of the statistics of Lebanese SMEs with 2,040 firm-annual observations adopted for this study.

Table 1. Mean, standard deviation, reliability, and correlation coefficient among Variables

\begin{tabular}{ccccc}
\hline Variables & Mean & Std.Dev & AD & PR \\
AD & 0.28 & 0.32 & & \\
PR & 0.13 & 0.18 & $0.1813^{* *}$ & \\
ST & 0.26 & 0.24 & 0.0845 & $0.2227^{* *}$ \\
\hline
\end{tabular}

Note: $* *$ denote significance level at $p<0.01$.

The descriptive statistics of explanatory variables and the significant correlations between determinants. The results demonstrate that profitability (PR) is significantly yet weakly correlated with access to debt (AD), which is consistent with the first hypothesis. However, although a weak correlation is confirmed between access to debt (AD) and assets structure (ST), it is not significant. Finally, the table also demonstrates the positive weak correlation between tangibility (ST) and profitability (PR).

\section{Linear Regression Model Assumptions and Diagnostic Tests}

According to Gujarati (2004, pp. 65) and Brooks (2008, pp. 129), the classical linear regression model (CLRM) is characterized by the following five assumptions. The multicollinearity test is not applicable as there is only one independent variable in each model.

The average value of the errors is zero $E(u t)=0$.

According to Brook (2008), if the regression equation has a constant term, then this assumption cannot be violated. Therefore, the first assumption is achieved, as each model has its own constant represented by a and b respectively.

The $x$ t are non-stochastic.

This assumption states that regressors should not be correlated with the error term (Brooks, 2008). The estimation model for this study was achieved using the GLS model, which is based on no correlation between regressors. Therefore, the regressors are not correlated with the compound error term.

The variance of the errors is constant var $(u t)=\sigma 2<\infty$ or homoscedasticity assumption.

Although ordinary least squares (OLS) is widely used to estimate the parameter of a linear regression model, OLS conclusions are generally wrong when there is heteroskedasticity, especially for panel data. According to White (1980), the existence of heteroskedasticity in a linear model is an indicator of inefficient parameter estimates and maladjusted covariance matrix estimates. Therefore, it is important to test the heteroskedasticity by using BreuchPagan test, specifically the Cook and Weisberg version. Table 2 lists that the P-values of the first and second models are greater than 0.05 , which means that there is no problem of variation of the random variable.

Table 2. Heteroskedasticity Test

\begin{tabular}{ccc}
\hline Hypotheses & Chi2 & P-value \\
\hline $1^{\text {st }}$ Model & 0.39 & 0.5308 \\
$2^{\text {nd }}$ Model & 0.67 & 0.4114 \\
\hline
\end{tabular}


The disturbances are normally distributed (ut $\sim N(0, \sigma 2)$ or normality assumption.

The disturbances or error terms are normally distributed. Normality test is implemented to verify if the error terms are normally distributed by applying Shapiro-Wilk test. The p-value should be more than 0.05 to accept the null of normality at the 5\% level. As shown in table no. 3 and 4 below both models residuals P-value are less than 5\% suggesting that the errors are not normally distributed. Therefore, the research rejects the null hypothesis of normality at the $5 \%$ significance level.

Table 3. $1^{\text {st }}$ Model Normality Test

\begin{tabular}{ccccc}
\hline Variables & $\mathrm{W}$ & $\mathrm{V}$ & $\mathrm{Z}$ & Prob $>\mathrm{z}$ \\
\hline $\mathrm{PR}$ & 0.83112 & 47.325 & 9.186 & 0.00000 \\
$\mathrm{AD}$ & 0.70943 & 81.423 & 10.478 & 0.00000 \\
\hline
\end{tabular}

Table 4. $2^{\text {nd }}$ Model Normality Test

\begin{tabular}{ccccc}
\hline Variables & $\mathrm{W}$ & $\mathrm{V}$ & $\mathrm{Z}$ & Prob $>\mathrm{z}$ \\
\hline $\mathrm{ST}$ & 0.87970 & 33.710 & 8.378 & 0.00000 \\
$\mathrm{AD}$ & 0.70943 & 81.423 & 10.478 & 0.00000 \\
\hline
\end{tabular}

To overcome this challenge, the researcher used robust procedure. Based on Box (1953), Alma (2011) violation to normality assumption can be treated using robust procedure stating that robust regression submits resistant results in case of outliers' presence.

The covariance between the error terms is zero $\operatorname{cov}(u i, u j)=0$ for $i=j$ or autocorrelation assumption

The existence of autocorrelation would imply a biased model, which affects the linearity assumption. The autocorrelation test measures linear relationships by examining the correlation between random variables' values at different points in time, which makes $\operatorname{Cov}(\varepsilon I, \varepsilon i-1) \neq 0$ for all i values (Safi, 2013). Autocorrelation occurs when time series data are affected by their own historical values (Wooldridge, 2005, p.354). While autocorrelation may appear in cross-sectional data, it occurs more often in time series data. There are several methods that can be used to test for autocorrelation, such as the DW (Durbin-Watson) test. The DW test applies OLS and extracts DU for the upper limit and DL for lower limits for the significance level of D, which represent the non-autocorrelation zone. STATA 14 did not accept the test for both models in this research, suggesting that there is an autocorrelation problem. To solve for autocorrelation and to obtain a more efficient estimator, the researcher employed generalised least square (GLS). GLS is usually adopted when an OLS estimator does not provide a linear unbiased estimation due to the existence of heteroskedasticity and autocorrelation (Wooldridge, 2005).

\section{The Selection of Model Analysis Method}

There are two primary methods of regression for panel data: fixed and random effects. We cannot use pooled OLS with panel data because it neglects the panel character of the dataset. The Hausman test in panel data helps to decide which approach to adopt (Gujarati, 2004). The Hausman test assumes two hypotheses. The null hypothesis indicates that the preferred model is the random effects method; thus, the study should use GLS. The Hausman test primarily examines if there is a correlation between the unique errors and the regressors in the model. The null hypothesis is that there is no correlation between the two. Based on the Hausman test results in Tables 5 and 6 below, the Chi Square value are high with significance levels of 0.0428 and 0.0156 respectively; therefore, the null hypotheses are accepted, confirming the use of fixed effects as the appropriate procedure for both models. 
Table 5. Hausman Test $-1^{\text {st }}$ Model

\begin{tabular}{ccccc}
\hline Variables & Fixed & random & Difference & Sqrt \\
\hline AD & .2244687 & .1756429 & .0488257 & .0241026 \\
& & & \multicolumn{2}{c}{ P-value $=0.0428$} \\
\end{tabular}

Table 6. Hausman Test $-2^{\text {nd }}$ Model

\begin{tabular}{ccccc}
\hline Variables & fixed & Random & Difference & Sqrt \\
\hline AD & .0636797 & .1187805 & -.0551008 & .0227969 \\
& & & P-value $=0.0156$ & \\
\hline
\end{tabular}

\section{Results of the Regression Analysis}

Table 7 below provides an estimated parameter for the first model after using the generalised least squares fixed method. According to the R-squared value, the independent variable, access to debt, explains $3 \%$ of the variance in profitability. The F-test value is 30.35 and the P-value for the test is less than 0.01, which confirms that the first standard model is properly fit for the data and can be used for predicting the profitability of Lebanese SMEs.

Table 7. 1st Model Estimated Parameters Using Fixed Effects

\begin{tabular}{cccc}
\hline Variables & Coefficient & Z- statistic & P-Value \\
\hline AD & .2244687 & 5.15 & 0.000 \\
Constant & .0692283 & 5.44 & 0.000 \\
F-test & 30.35 & & 0.000 \\
R-Squared & & 0.0329 & \\
\hline
\end{tabular}

As for the second model, Table 8 provides an estimated parameter using the fixed effect method. According to the $\mathrm{R}$-squared value, the independent variable, access to debt, explains only $0.07 \%$ of the variance in assets structure. The F-test value is 16.25 , while the P-value for the test is less than 0.01 , which confirms that the second standard model is also properly fit for the data and can be used for predicting the assets structure of Lebanese SMEs.

Table 8. $2^{\text {nd }}$ Model Estimated Parameters Using Fixed Effects

\begin{tabular}{cccc}
\hline Variables & Coefficient & Z- statistic & P-Value \\
\hline AD & .1298585 & 4.08 & 0.000 \\
Constant & .2308391 & 23.19 & 0.000 \\
F-test & 16.25 & & 0.0001 \\
R-Squared & & 0.0071 & \\
\hline
\end{tabular}

\section{Discussion}

The regression analysis results support the first hypothesis that access to debt has a positive significant effect on profitability of SMEs, which indicates that Lebanese SMEs should adopt a TOT perspective. This result is in line with the previous studies of Mateev and Anastasov (2010), Li et al. (2012), Wang (2013), Ramadan (2015), Manini et al. (2016) and Hamouri et al. (2018). However, this result is in contradiction to the studies of Goldhausen (2017), Kebewar (2012), Kebewar (2013), Iavorskyi (2013), Nawi (2015), Schulz (2017) and Malaeny et al. (2018). As the study does not differentiate between short-term debt and long-term debt, it cannot agree nor disagree with Baum et al. (2007), Yazdanfar (2012), Wahba (2013) or Abeywardhana (2015), because these studies found mixed results for short-term and long-term access to debt. Based on these results, it is clear that Lebanese SME managers understand the benefits of access to debt in terms of tax shields and know that financing can increase the firm value and help 
SMEs to develop, expand and grow by financing productive assets and initiating successful projects. However, SME managers also realise that dependence on limited internal funds by SMEs will hinder them in seizing opportunities, taking risks and growing. Therefore, Lebanese SME managers use TOT to trade off between the cost of capital for financing, the benefits of tax shields and the expected return of a potential project before requesting access to debt, which increases the profitability of Lebanese SMEs.

As for the effect of access to debt on tangibility, the regression analysis results support the second hypothesis that access to debt has a positive significant effect on the assets structure of SMEs, further confirming that Lebanese SMEs adopt a TOT perspective. This result is in line with the previous studies of Jeger et al. (2016), but contradicts with the conclusions of Nawi (2015). In addition, as this research does not differentiate between short-term debt and long-term debt, it cannot agree or disagree with Andree and Kallberg (2008). Based on the regression analysis results, it is clear that Lebanese SMEs apply the matching principal to take advantage of the tax shield of long-term-debt and to finance current assets with short-term debt. These actions minimise the interest rate costs and give SMEs the opportunity to initiate profitable projects and consequently grow. However, the separation of types of debt is required to confirm this proposition. Therefore, future studies should focus on the effect of access to debt on assets structure, as it is an important variable that can predict the future of SMEs, as argued by Jeger et al. (2016).

\section{Theoretical Implications}

This study provides new insights into the positive direct effect of access to debt on Lebanese SMEs. In addition, it presents the financial behaviour of Lebanese SMEs and lenders by adopting a trade-off theory perspective. The first impresion based on the empirical evidence on Lebanese SMEs' financial behaviour is their adoption of an optimal leverage ratio that maximises profit and minimises finance costs. By adopting TOT, we can confirm the awareness of managers of Lebanese SMEs around the benefit of access to debt to finance their operations by trading off between capital costs and prospected profit. However, it is not clear if SMEs managers use the maturity principal to finance current assets with short-term debt and fixed assets with long-term debt, as this study does not separate between longterm debt and short-term debt. Furthermore, it is surprising that access to debt affects profitability of SMEs much more than it affects tangibility. This finding may be related to the declining economy of Lebanon since 2009 (World Bank, 2015), which is important for understanding how SMEs utilise the acquired debts.

\section{Practical Implication}

This research holds significant value for practioners, especially for managers of start-ups and SMEs. This study can be utilised by managers to know which financial approach is adopted by Lebanese SMEs. SME managers should define their optimal leverage ratio and use access to debt to maximise their profits and minimisse the capital cost instead of depending on retained earnings to finance growth or improve performance. In addition, managers can use different suggested factors in this research to evaluate their performance, such as assets growth, number of employees, return on assets, innovation and exports, instead of focusing on sales turnover and profit. Moreover, this study provides an opportunity for practioners to explore the maturity principal to lower costs and maxmise profits related to type of debt. Finally, this research offers managers with a perspective on how SMEs are affected by the economy, which leads them to utilise debt in improving SMEs profitability instead of tangiblity.

\section{Conclusion}

The study presents empirical evidence on the effect of Lebanese SMEs' access to debt on profitability and assets structure. The study also provides insights into the approach that Lebanese SMEs adopt behind profitability and assets structure as financial behaviour to deal with access to debt in terms of trade-off theory versus pecking order theory. The researcher collected data on 102 SMEs for the period 2014-2017 from 12 official audit firms located in Beirut, Lebanon. Two models were created to examine the effect of Lebanese SMEs' access to debt on profitability and assets structure respectively. The generalised least squares method was used to conduct a regression analysis. The findings confirm a positive effect of Lebanese SMEs' access to debt on profitability and assets structure. These positive relationships confirm the adoption of trade-off theory by Lebanese SMEs. Therefore, it can be concluded that Lebanese SMEs commit to a target ratio of debt and equity by trading off between the level of debt and bankruptcy risk represented by the annual interest rate, principal payment, legal and accounting expenses and risk of losing customers, employees or suppliers. This trade-off helps SMEs to minimise financing costs, maximise profits, 
take advantage of tax shields and increase the value of the firm by reaching the proper debt-equity ratio. In addition, the findings indicate that Lebanese SMEs use the matching principal to minimise the interest rate costs and to create an opportunity to initiate profitable projects and consequently grow, which reflects the understanding of Lebanese SMEs managers on how access to debt can positively affect firm value, profitability, assets structure and ultimately growth and expansion.

\section{Limitations and Further Research}

Several limitations characterise this study. The limitations are sample size, which can affect the results, and excluded factors or measures, such as managerial characteristics, that have not been considered and may provide further explanation of the effect of access to debt on SME profitability and assets structure. In addition, distinguishing between short-term debt and long-term debt would allow for more comprehensive analysis and offer insights into the application of the matching principle by Lebanese SMEs. Another important limitation is the effect of other factors on access to debt, profitability and assets structure, such as the economic or political situation. Moreover, future studies may integrate different sources of data to increase the research generalisability. Different data sources may lead to different results, especially given the lack of financial data transparency in developing countries.

\section{Acknowledgements}

The authors received no financial support for the competition of this research.

\section{References}

Abeywardhana, D. K. Y. (2015). Capital Structure and Profitability: An Empirical Analysis of SMEs in the UK. Journal of $\begin{array}{lllll}\text { Emerging Issues } \quad \text { Economics, } & 4(2), & 1-14 . & \text { https://www.resea }\end{array}$ rchgate.net/publication/285596953_Capital_Structure_and_Profitability_An_Empirical_Analysis_of_SMEs_in_the_UK

Alma, O. G. (2011). Comparison or Robust Regression Methods in Linear Regression. International Journal Contemporary Mathematical Sciences, 6(9), 409-421.

Alibhai, S., Bell, S. and Conner, G. (2017). What's Happening in the Missing Middle? Lessons from Financing-SMEs. International Bank for Reconstruction and Development. World Bank Group. http://documents.worldbank.org/curated/en/707491490878394680/pdf/113906-WhatsHappeningint heMissingMiddleLessonsinSMEFinancing-29-3-2017-14-20-24.pdf

Ando, K., Matsumoto, K. and Matsumoto, Y. (2017). Business Performance of Firms Using Debt. Policy Research Institute; Ministry of Finance-Japan; Public Policy Review, 13(2), 167-182. https://www.mof. go.jp/english/pri/publication/pp_review/fy2017/ppr13_02_05.pdf

Andree, C. \& Kallberg, C. (2008). The Capital Structure Puzzle of SMEs-Evidence from the Swedish Security Industry. Master Thesis, Ekonomi Hogskolan-Lunds Universitet, Sweden.

Ayuso, S. and Navarrete-Baez, F. E. (2018). How Does Entrepreneurial and International Orientation Influence SMEs' Commitment to Sustainable Development? Empirical Evidence from Spain and Mexico. Corporate Social Responsibility and Environmental Management, 25, 80-94.

Baum, C. F., Schafer, D. and Talavera, O. (2007). The Effects of Short-Term Liabilities on Profitability: The Case of Germany. Money Macro and Finance (MMF) Research Group Conference 61, Money Macro and Finance Research Group. http://repec.org/mmf2006/up.25583.1145029704.pdf

Box, G. (1953). Non-normality and tests on variances. Biometrika, 40, 318-335.

Brooks, C. (2008). Introductory: Econometrics of finance. (2nd Ed.). Cambridge University Press, The ICMA Centre.

Carter, S. and Evans, J. D. (2000). Enterprise and Small Business-Principles, Practice and Policy. (1st Ed.). Pearson Education Limited.

Davidsson, P., Achtenhagen, L. \& Naldi, L. (2006). What do we know about small firm growth? In Parker, C.S. (Eds.), The Life Cycle of Entrepreneurial Ventures pp. 361 - 398. Springer, New York, USA.

Daskalakis, N. and Pasillaki, M. (2006). The Determinants of Capital Structure of the SMEs: Evidence from the Greek and the French Firms. XXIInd Symposium on Banking and Monetary Economics, Strasbourg. https://www.researchgate.net/publication/228346743_The_Determinants_of_Capital_St

ructure_of_the_SMEs_Evidence_from_the_Greek_and_the_French_firms.

Delmar, F., Davidsson, P. \& Gartner, W. B. (2003). Arriving at the high-growth firm. Journal of Business Venturing, 18(2), 189216. http://citeseerx.ist.psu.edu/viewdoc/download?doi=10.1.1.550.5499\&rep=rep1\&type=pdf.

Dennis, K. K., Achesa, K. \& Gedion, O. (2015). Effect of Microfinance Credit on the Performance of Small and Medium Enterprises in Uasin Gishu County, Kenya. International Journal of Small Business and Entrepreneurship Research, 3(7), 57- 
78. http://www.eajournals.org/wp-content/uploads/Effects-of-Microfinance-Credit-On-the-Performance-of-Small-andMedium-Enteprises-in-Uasin-Gishu-County-Kenya.pdf.

Domnick, C. H. (2018, July). Influence of capital structure on firm's financial performance: An Inter-Industry Investigation of German Listed Firms, 11 $1^{\text {th }}$ IBA Bachelor Thesis Conference, Enschede-The Netherlands. https://essay.utwente.nl /75458/1/Domnick_BA_BMS.pdf

Ehrhardt, M. C. and Brigham, E. F. (2011). Financial Management: Theory and Practice (13th Ed.). USA: South-WesternCengage Learning.

European Investment Bank (2011). Report on Support to SMEs in Developing Countries Through Financial Intermediaries, https://www.eib.org/attachments/dalberg_sme-briefing-paper.pdf

Everitt, B. S. (2002). The Cambridge Dictionary of Statistics (2nd Ed.). Cambridge University Press.

Goldhausen, J. (2017). Access to Finance and Growth: Evidence from Dutch SMEs. ( $^{\text {th }}$ IBA Bachelor Thesis Conference, Enschede, The Netherlands; University of Twente. https://essay.utwente.nl/72691/1/Goldhausen_BA_BMS.pdf

Gujarati, D.N. (2004). Basic econometrics. (4th Ed.). McGraw-Hill Companies.

Hall, G., Hutchinson, P. and Michaelas, N. (2000). Industry Effects on the Determinants of Unquoted SMEs' Capital Structure. International Journal of the Economics of Business. 7, 297-312.

Hamouri, B., Al-Rdaydeh, M. and Ghazalat, A. (2018). Effect of Financial Leverage on Firm growth: Empirical Evidence from Listed Firms in Amman Stock Exchange. Investment Management and Financial Innovations, 15(2), 154-164. https://businessperspectives.org/images/pdf/applications/ publishing/templates/article/assets/10371/imfi_2018_02_Hamouri.pdf.

Harc, M. (2015). The relationship between tangible assets and capital structure of small and medium-sized companies in Croatia. Ekonomski Vjesnik-Econviews, XXVIII, 213-224.

Harvie, C., Narjoko, D. and Oum S. (2013). Small and Medium Enterprises' Access to Finance: Evidence from Selected Asian Economies. Paper series No. 23, Economic Research Institute for ASEAN and East Asia.

Iavorskyi, M. (2013). The Impact of Capital Structure on Firm Performance: Evidence from Ukraine. Master Thesis, Kyiv School of Economics, Ukraine.

International Monetary Fund (IMF) and World Bank (2016). Financial Sector Assessment: Lebanon. Financial Sector Assessment Program (FSAP). Washington. Retrieved 5 January 2018 from http:// documents.worldbank.org/curated/en/260481485486059075/Lebanon-FSAP-Update-FSA-12222016.docx

Jeger, M., Sarlija, N. \& Bilandzic, A. (2016). Financial Determinants of SMEs Growth in The Time of Economic Downturn. Ekonomiski Vjesnik, XXIX(2), 335-345. https://pdfs.semanticscholar.org/94db/6afc7 9707494a872206650ec64be84af23a0.pdf?_ga=2.116670144.753554743.1571819258-904311070.1570699121.

Kaseb, S. and Kamal El Din, J. (2007). Small Enterprises - Opportunities and Challenges. (1st Ed.). The Center for Advancement of Post-Graduate Studies and Research in Engineering Sciences C.A.P.S.C.U).

Kebewar, M. (2012). The Effect of Debt on Corporate Profitability: Evidence from French Service Sector. Brussels Economic Review, 56(1), 43-59. https://papers.ssrn.com/sol3/papers.cfm?abstract_id=2444413.

Kebewar, M. (2013). Does debt affect Profitability? An empirical study of French trade sector. halshs-00780310; https://halshs.archives-ouvertes.fr/halshs-00780310.

Kerlinger, F. N. (1992). Foundations of behavioral research. (3rd Ed.). New York: Harcourt Brace College.

Kokoreva, M. \& Stepanova, A. (2012). Financial Architecture and Corporate Performance: Evidence from Russia. Journal of Corporate Finance Research, 2(22), 34-44. https://economics.hse.ru/data/2012/10/10/1247119710/ cfj22_34_44_Kokoreva_Stepanova_.pdf.

Kythreotis, A., Nouri, B. A. and Soltani, M. (2018). Determinants of Capital Structure and Speed of Adjustment: Evidence from Iran and Australia. Sciedu Press, 9(1), 88-113. http://sciedupress.com/journal/index.php/ijba/article/view/12918/7990.

Li, L., Jinfeng, C. \& Xuezhu, G. (2012). The Growth Evaluation Model of Manufacturing SMEs and Application from System Engineering Perspective. Systems $\quad$ Engineering Procedia, 4 5, 419.https://www.researchgate.net/publication/271609949_The_Growth_Evaluation_Mo del_of_Manufacturing_SMEs_and_Application_from_System_Engineering_Perspective

Malaeny, S., Pasda, S. and Haerani, St. (2018). Effects of Capital Management on Business Performance of Small and Medium Enterprises in Restaurant Sectors. IOSR Journal of Business and Management (IOSR-JBM, 20(3), 76-83. http://www.iosrjournals.org/iosr-jbm/papers/Vol20-issue3/Version-1/L2003017683.pdf.

Manini, M. M., Abdillahi, U. A., Wanyama, K. and Simiyu, J. (2016). Effect of Business Financing on the Performance of Small and Medium Enterprises in Lurambi Sub-County, Keny. European Journal of Business and Management, 8(2), 1-21. https://pdfs.semanticscholar.org/8a76/01cce2d4e1866617bc77afbd65a6fb11c904.pdf?_ga=2.16456304.753554743.15 71819258-904311070.1570699121.

Mateev, M. \& Anastasov, Y. (2010). Determinants of Small and Medium Sized Fast Growing Enterprises in Central and Eastern Europe: a panel data analysis. Financial Theory and Practice, 34(3), 269-295. https://hrcak.srce.hr/file/94662.

Matta, J. M. (2018). M/SMEs in Lebanon: Status, Strategy and Outcomes. Ministry of Economy and Trade, Lebanon. Retrieved 5 January 2018 from https://www.unescwa.org/sites/www.unescwa.org/files/events/files/johnny-matta-small-mediumenterprise-lebanon-en.pdf 
Ministry of Economy and Trade (2014), Lebanon SME Strategy: a Roadmap to 2020, Retrieved 5 January 2018 from https://www.economy.gov.lb/public/uploads/files/6833_5879_4642.pdf.

Moreira, D. F. (2016). The microeconomic impact on growth of SMEs when the access to finance widens: evidence from internet \& high-tech industry. Social and Behavioral Sciences, 220, 278-287. https://core.ac.uk/download/pdf/82188888.pdf.

Muller, P., Devnani, S., Julius, J., Gagliardi, D. and Marzocchi, C. (2016). Annual Report on European SMEs 2015/2016-SME Recovery Continues. European Union, Contract number: EASME/COSME/2015/012. https://ec.europa.eu/jrc/sites/jrcsh/files/annual_report_-_eu_smes_2015-16.pdf

Naimy, V. Y. (2004). Financing Problems Faced by The Lebanese SMEs: An Empirical Study. The International Business \& Economics Research Journal, 3(1), 27-38.

Nawi, H. M. (2015). Determinants of Capital Structure in Small and Medium-Sized Enterprises in Malaysia. PHD dissertation, Brunel University London, United Kingdom.

Ramadan, I. Z. (2015). Leverage and the Jordanian firms' value: empirical evidence. International Journal of Economics and Finance, 7(4), 75-81. https://pdfs.semanticscholar.org/94ef/697c24698feb765deac7621cc7a154ff63e5.pdf.

Popa, A. E. and Ciobano, R. (2014). The Financial Factors that Influence the Profitability of SMEs. International Journal of Academic Research in Economics Management http://hrmars.com/index.php/journals/papers/IJAREMS/v3-i4/1117

Ross, S. A., Westerfield, R. W. \& Jaffe, J. (2013). Corporate Finance. (10th Ed.). USA: McGraw-Hill Irwin.

Safi, S. K. (2013). An Introduction to Loading Regression Models Using EViews. (1 ${ }^{\text {st }}$ ED.). Dar Afaq for Publish, Palestine.

Shergill, J., \& Sarkaria, M. (1999). Impact of Industry type and firm characteristics on firm-financial performance: Evidence from Indian industry level. Journal of Entrepreneurship, $\quad 8(1)$, 25-44. https://journals.sagepub.com/doi/10.1177/097135579900800102.

Schulz, T. (2017). The Impact of Capital Structure on Firm Performance: an Investigation of Dutch Unlisted SMEs. $9^{\text {th }}$ IBA Bachelor Thesis Conference, The Netherlands, University of Twente. https://essay.utwente.nl/72690/1/Schulz_BA_BMS.pdf

Scarborough, N. M. (2011). Essentials of Entrepreneurship and Small Business Management. (6th Ed.). England: Pearson Education Limited.

Tang, Y. (2014). Trade Credit and Profitability in Small and Medium Enterprises. $3^{\text {rd }}$ IBA Bachelor Thesis Conference, July $3^{\text {rd }}$, Enschede, The Netherlands.

United Nations (2019). Micro-Small and Medium-sized Enterprises Day 27 June. Retrieved 5 January 2018 from http://www.un.org/en/events/smallbusinessday/.

Vandenberg, P., Chantapacdepong, P. and Yoshino, N. (2016). SMEs in Developing Asia: New Approaches to Overcoming Market Failures. Asian Development Bank Institute, Tokyo, https://www.adb.org/sites/default/files/publication/214476/adbismes-developing-asia.pdf

Vijayakumaran, R. (2017). Capital Structure Decisions and Corporate Performance: Evidence from Chinese Listed Industrial Firms. International Journal of Accounting and Financial Reporting, 7(2), 562-576. https://www.researchgate.net/publication/324646096_Capital_Structure_Decisions_and_Corp orate_Performance_Evidence_from_Chinese_Listed_Industrial_Firms.

Wahba, H. (2013). Debt and Financial Performance of SMEs: The Missing Role of Debt Maturity Structure. Corporate Ownership and Control, 10(3), 354-365. http://www.virtusinterpress.org/IMG/pdf/10-22495_cocv10i3c3art2.pdf.

Wang, X. (2013). The Impact of Microfinance on the Development of Small and Medium Enterprises: The Case of Taizhou, China. The John Hopkins University, http://citeseerx.ist.psu.edu/viewdoc/summary?doi=10.1.1.361.6446

White, H. (1980). A heteroskedasticity-consistent covariance matrix estimator and a direct test for heteroscedasticity. Econometrica, 48(4), 817-38.

Wooldridge, J.M. (2005). Introductory Econometrics: A Modern Approach. (3rd Ed.). Canada: Thomson-Westerm.

World Bank (2008). Finance for All? Policies and Pitfalls in Expanding Access. The International Bank for Reconstruction and Development, https://siteresources.worldbank.org/INTFINFORALL/Resources/4099583-1194373512632/FFA_book.pdf

World Bank (2015). Lebanon Economic Monitor: The Great Capture. http://documents.worldbank.org/curated/ en/397721468185952923/pdf/101022-WP-PUBLIC-disclosed-11-18-4am-DC-time-11am-Beirut-Box393257B-The-WorldBank-LEM-Fall-2015.pdf

Yazdanfar, D. (2012). The Impact of Financing Pattern on Firm Growth: Evidence from Swedish Micro Firms. International Business Research. 5(9), 16-25. http://www.ccsenet.org/journal/index.php/ibr/article/download/19395/12861

Zhou, H. \& Wit, G. d. (2009). Determinants and Dimensions of Firm Growth. Scientific Analysis of Entrepreneurship and SMEs, EIM Research Reports, Ref. H200903. http://ondernemerschap.panteia.nl/pdf-ez/h200903.pdf.

5Index Business Directory (2018), Retrieved 16 May 2018 form http://www.5index.com/.

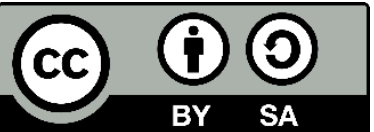

(C) 2020 by the authors. Licensee ACRN Publishing, Austria, Editor in Chief Prof. Dr. Othmar M. Lehner. This article is an open access article distributed under the terms and conditions of the Creative Commons Attribution (CC BY SA) license (https://creativecommons.org/licenses/by-sa/4.0/) 